\title{
Elu Sõna koguduse algusest ja tööst Eestis, eriti Tartus
}

\section{$\underline{\text { Tiina Eier }}$}

\section{Algus}

Elu Sõna kogudus Tallinnas sai alguse 1986. aastal, olles kasvanud välja Oleviste baptistikoguduses ja metodistikoguduses võimsalt alanud Püha Vaimu liikumistest. Aluseks võeti Rootsi Elu Sõna piibliõpetaja Johnny Foglanderi tollal ülirevolutsiooniline õpetus vaimsest sõjapidamisest ning Kenneth Hagini õpetus meelevallast Püha Vaimu väes, mis tegelikult tähendas, et mistahes pimeduse rõhumine, kaasa arvatud kommunism, alistub siis, kui kristlased üksmeelselt ning mitte malbelt, vaid sõjakalt palvetavad.

1988. aastal sündis Tartu Elu Sõna kogudus seoses Kunstiinstituudi pooleli jätnud ning koguduse rajamiseks Jumala kutset tundnud Albert Türnpu tagasipöördumisega kodulinna. Algasid tollasel ajal harjumatult julged avalikud ülesastumised rahvakogunemistel ning tormilised KGB jälitatud kodukoosolekud Rein Seppa korteris Ränilinnas (FI linnajaos), mida külastati vaatamata jälitamisele KGB poolt ning mis tõid kaasa eheda pöördumistelaine üliõpilaste ja teiste noorte seas: päästetud sai inimesi igal järjekordsel kogunemisel.

Elu Sõna sai kuulsaks kui rõõmsameelne ja karjääriga mitte riskida kartvate hulljulgete noorte kogudus ning sellega julgesid end häbenemata siduda mitmed tuntud muusikud.

Ametliku alguseni jõuti 1990. aasta märtsis, kui Usuasjade osakond pärast pikki lahinguid koguduse registreeris. Peale korrapäraste koosolekute viis Albert Türnpu koos abikaasa Heliga läbi ülipõnevaid piiblikoolitunde ja teinekord tunde kestvaid palvekoosolekuid.

\section{Piibliseminar}

1990. aastal algas uus etapp koguduse arengus: alustas tegevust Tartus Elu Sõna Piibliseminar. Et piibliseminar oli oma algusaastatel 1990-1992 ainus sellelaadne õppeasutus NL-i (alates 1991. aasta sügisest juba endise NL-i) alal üldse, levisid kuuldused sellest kaugele (Habarovsk, Abakan, Jerevan, Lvov, Jakutsk, Kiiev). Tulijad olid valmis maksma õppimise eest ränka hinda: kannatama tagakiusu, mis neile kui võõrõpilastele ning tulistele kristlastele osaks sai, samuti leppima tagasihoidlike elamistingimustega, mis kõik ei vähendanud aga nälga Jumala järele. Paljudest neist, peamiselt Venemaalt ja Ukrainast tulnutest, on saanud tugevad pastorid ja koguduseliikmed, kiindunud Jumalasse, tuntud oma kodulinnades ja -maades. Misjonireisidel kohtab Albert Türnpu tihti õpilasi, kes on talle tänulikud, et võivad nüüd Jumalat teenida.

Esimese piiblikoolilennu «suvepraktikaks» osutus Tamme staadionil aset leidnud Peter Yanggreni suurevangelisatsioonil (külastajaid mitme päeva lõikes arvatavalt 15000 ) kaasalöömine: ülistuse läbiviimine ning muud koosolekutega seotud praktilised ülesanded.

Alates 1994. aastast olid Elu Sõna piibliseminarlased olnud pärit enamasti kas Lätist või Eestist. Aastaks 2000 on selles õppinud ühtekokku veidi alla 1000 inimese. 


\section{Koguduse töö}

1994. aasta märgib keskendumist tööle Eestis. Sellel aastal rajati koguduse baasil mitmed olulised tööharud: ühiskondlik organisatsioon Elu Liit, mis tegeleb elupooldava informatsiooni tutvustamisega koolides ning aborti piiravate muudatuste taotlemisega seadusandluses; kuulehena alustanud ja nüüdseks nädalaleheks saanud Elu Sõna Leht, mis käsitleb ka teiste koguduste ning kogu ühiskonna elu, levides samuti väljapoole ning olles muude perioodikaväljaannete taoliselt ettetellitav; põhikoolihariduse andmiseks vajalikku koolitusluba omav Elu Sõna Kristlik Kool, kus praegu tegutseb seitse klassi ning õpivad lapsed ka mittekristlikest peredest; ühiskondlik organisatsioon Iisraeli Sõbrad, mille juures tegutsev ansambel korraldab juudi pärimusmuusika kontserte juutidele, veendes neid kodumaale, Iisraeli, pöörduma.

Elu Sõna korralised koosolekud Tartus on igal neljapäeval kell 19.00 ning pühapäeval kell 10.00. Lastele mõeldud erikoosolek: «Laupäev koos Jeesusega» toimub samas laupäeviti kell 12.00. Peale selle korraldatakse temaatilisi seminare tuntud välismaiste evangelistide ja õpetajatega, samuti ulatuslikumaid koverentse paljude kõnelejatega. Tavaliselt toimub igal aastal suve- ja uusaastakonverents.

Laienenud on ka Elu Sõna haare: sellenimelisi kogudusi on nüüdseks Viljandis, Rakveres, Valgas, Tallinnas, Jõgeval ja Põlvas. Kõigis neis linnades on käivitunud regulaarne kogudusetöö: peetakse teenistusi, ööpalveid, osaletakse palvegruppides, kuhu koondutakse huvialade või elurajoonide järgi, korraldatakse tänavaevangelisatsioone ja lasteetendusi.

Siiski ei piirdu teenistus, mille Jumal on sellele kogudusele andnud, ainult Eestiga (Albert Türnpu on oodatud jutlustaja nii Venemaal, Lätis, Ukrainas, Rootsis, Ameerikas kui Iisraelis) ega nn kristlike valdkondadega. Jumal on mitmeid kordi tõestanud, et teadmise sõna, mille pastor on ühe või teise (ühiskondliku) nähtuse kohta öelnud, täitub, näiteks prognoosid, keda toetada valimistel, mis saab ühest või teisest poliitilisest jõust ning mis on olulised tegevussuunad järgnevate aastate lõikes.

Seega kannab Elu Sõna Kogudus aulist ja vastutusrikast prohvetlikku missiooni, mis, hoolimata sellest, kas see inimestele meeldib või mitte, on mõeldud terve rahva, mitte grupi kristlaste teenimiseks.

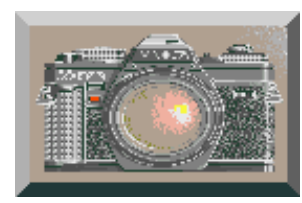

Pilte Elu Sõna tegevusest

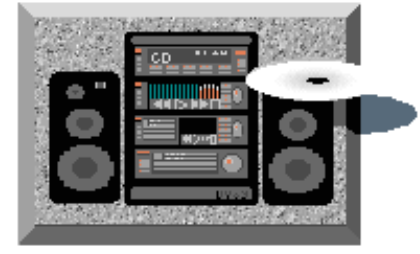

Näen Eestit, mis püha $4.1 \mathrm{Mb} . \mathrm{mp} 3$ fail 